
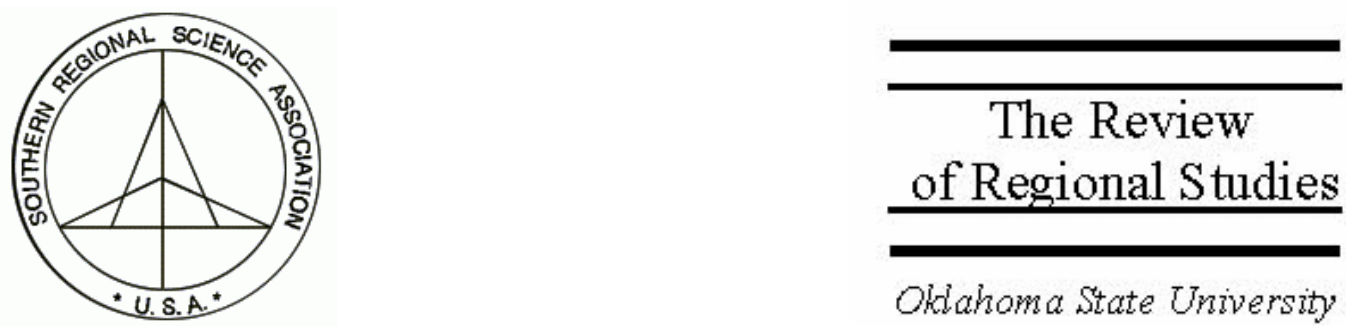

\title{
Laying the Foundation for Employment: The Role of Social Capital in Educational Achievement
}

\author{
Glenn D. Israel \\ Program Development and Evaluation Center, University of Florida, PO Box 110540, \\ Gainesville, FL 32611-0540, e-mail: gdi@ifas.ufl.edu.
}

\section{Lionel J. Beaulieu}

Southern Rural Development Center, Box 9656, Mississippi State, MS 39762-9656, e-mail: ljb@srdc.msstate.edu

\begin{abstract}
This paper examines the role of social capital - the set of supportive interpersonal interactions that exists in the family, community, and school - in promoting educational achievement. Employing data on public school students from the National Education Longitudinal Survey (NELS) and other secondary data sources, we examine the link between students' access to social capital and important educational benchmarks, especially standardized test scores for math and reading. Building on previous research, we attempt to refine the conceptualization and measurement of social capital. We then undertake a new exploration of test score gains realized by students over the course of the $8^{\text {th }}$ to $12^{\text {th }}$ grades in order to assess the extent to which social capital attributes of the family, school, and community contribute to such gains. Finally, we outline the implications of our findings in guiding education policy activities in rural America.
\end{abstract}

Keywords: Academic achievement; Community; Rural development; Social capital

JEL classification: I21; I28; O18

This research is part of Florida Agricultural Experiment Station Project FLA-AEC-03957. 


\section{INTRODUCTION}

Unlike past decades, the creation of vibrant and sustainable economies in rural America is becoming increasingly tied to the educational credentials and training skills of the local workforce (Aldrich and Kusmin 1997; Gibbs, Swaim, and Teixeira 1998; McCall 1997). Increasingly, firms are settling in rural areas that have a sufficient pool of well-educated workers or a labor force capable of learning needed skills (Gale, Wojan, and Olmsted 2002; McGranahan 2002). At the same time, such firms want localities that take the education of their children seriously - places that invest in the education of tomorrow's workforce. Moreover, communities that have an excellent education system are better positioned to stem the out-migration of young, talented residents and are better able to attract in-migrants with strong human capital attributes (Barkley, Henry, and Shuming 1998).

If excellence in educational achievement, individually and collectively, is a key ingredient in promoting rural prosperity, then understanding the factors that contribute to achievement is crucial. For example, past research, such as the often-cited Coleman Report released nearly four decades ago, noted that family socioeconomic status (SES) has a powerful impact on student achievement (Coleman et al. 1966) and argued that educational outcomes are affected by factors present within and outside the school environment. Thirty years later, Lerner (1995) noted those public investments in families and community organizations were as vital as those targeted to schools in promoting student achievement.

An expanding body of work suggests that social capital - the set of supportive interpersonal interactions that exists in the family, community, and school - plays a decisive role in promoting educational achievement. Social capital has been applied by an array of researchers to study educational outcomes (see Coleman 1988; McNeal 2001; Morgan and Sørensen 1999; Parcel and Dufur 2001; Teachman, Paasch, and Carver 1997). In this context, social capital exists in the extent, quality, and application of relationships that advance or hinder the educational process.

This article offers a reformulation of the links between social capital and educational outcomes. It seeks to refine the conceptualization and measurement of social capital attributes that might have bearing on the educational progress of young people. This is realized by controlling for native abilities of students as well as the pool of resources available to families, schools, and communities that can impact student performance. By doing so, we are better able to isolate the key features of families, schools, and communities that shape the level of social capital in these settings. We argue that the nature and strength of social capital has direct bearing on the educational success of school-aged children.

Using a sample of public school students from the National Education Longitudinal Survey (NELS), we estimate the unique contributions of family, school, and community social capital attributes to achievement in $8^{\text {th }}$ grade, measured through standardized test 
scores administered as part of the NELS. We also examine test score gains realized by students between their $8^{\text {th }}$ and $12^{\text {th }}$ grades. This is undertaken to determine whether and to what extent family, school, and community social capital factors contribute to these gains. The final section of this article discusses the implications of our findings, giving special attention to the set of educational policies that can help to improve the social and economic prospects for communities in rural America.

\section{DETERMINANTS OF EDUCATIONAL ACHIEVEMENT}

\subsection{Innate Abilities and Other Background Attributes that Impact Learning}

Over three decades ago, Duncan, Featherman, and Duncan (1972) noted that certain ascribed statuses affect the life chances of individuals. These include race, ethnicity, and gender. According to Coleman (1988), these factors constitute the disadvantages of background. Recent works such as the volume by Flora, Flora, and Fey (2004) suggest that legacies of gender, race, and ethnicity continue to shape the educational aspirations that parents have for their children, or the expectations that teachers have for their students. Beyond these background attributes, students vary according to innate cognitive ability. Gifted students, for example, are better positioned to enroll in higher-level courses (e.g., advanced math courses) that have important bearing on their test scores. Moreover, academic performance in prior grades has much to say regarding the student's subsequent success.

\subsection{Available Resources and Student Opportunities}

The level of resources available to students at home, in school, or in the community, can "complement, reinforce, and add to their school experiences" (U.S. Department of Education 2003, p.73). These include the availability of books, a home computer, Internet access, personal tutors, and other educational products or activities. Other investments by parents include enrolling children in music classes, visiting museums, or taking part in other cultural activities (Downey 1995; Schneider 1993). As resources available to children in the home increase, the academic performance and school completion rates of these students improve (Coleman et al. 1966; Downey 1995; Israel, Beaulieu, and Hartless 2001; U.S. Department of Education 2003; Teachman, Paasch, and Carver 1997).

The level of monetary resources available to schools can have an impact on the learning environment and educational achievement (Greenwald, Hedges, and Laine 1996; Mortimore et al. 1988; Wenglinsky 1997). Resources affect the quality of school buildings, equipment for classrooms, books, and other instructional resources as well as teacher salaries (Stockard and Mayberry 1992; Turner et al. 1986). While some studies show little relationship between expenditures and achievement, the linkage is more apparent when resources are focused on specific programs (Arum 1998; Stockard and Mayberry 1992). 
The level of resources available to support schools is inextricably linked to the financial resources that communities are willing or able to dedicate to their schools. Localities with greater socioeconomic capacity can support a variety of institutions and organizations that help meet the daily needs of its citizens and have a cadre of people with extensive experience, knowledge, and expertise to guide local activities or to attract quality jobs. Furthermore, such communities often have greater access to outside resources to help deal with an array of community issues (Luloff and Wilkinson 1979).

In most instances, the socioeconomic capacity of rural areas has lagged behind that of suburban and urban areas. Lower-skilled, low-paying production jobs have been concentrated in rural areas, while more highly skilled managerial and technical positions have clustered in urban places (Hobbs 1995; Jensen and McLaughlin 1995). Lowcapacity rural towns, where educational attainment, income levels, job skills, and community engagement are more limited, can create a milieu that does not place a high priority on education. This may reduce rural students' educational achievement and aspirations relative to those of urban and suburban students (Cobb, McIntyre, and Pratt 1989; Smith, Beaulieu, and Seraphine 1995). ${ }^{1}$

\subsection{Social Capital and Student Achievement}

A number of recent studies have shown that the nature and level of social capital accessible to students can promote educational achievement (Beaulieu and Israel 1997; Israel, Beaulieu, and Hartless 2001; Smith, Beaulieu, and Israel 1992; Smith, Beaulieu, and Seraphine 1995). Social capital refers to what Coleman (1990, p.334) describes as the set of norms, social networks, and relationships between children and their families, schools, and communities that are of value as they grow up. Expanding on Coleman's notion of social capital, Stockard and Mayberry (1992, p.74) note that "it involves obligations, behavioral expectations, and trust that develop from strong ties among individuals in a group, channels of information that help people be more informed, and norms of effective sanctions that facilitate and constrain certain actions.”

Smith, Beaulieu, and Seraphine (1995) further elaborate Coleman's notion of social capital by suggesting that it embraces both structure and process features, elements that work in a complementary fashion to condition the environment for educational achievement. Structure, for example, determines the opportunity for, as well as the frequency and duration of, interpersonal interactions. Process, on the other hand, represents the level of involvement of individuals or institutions in the lives of youth. Both structure and process aspects of social capital can be found in the family, school, and community.

\footnotetext{
${ }^{1}$ According to Hobbs (1995), many rural communities cannot fully capture the benefits of their investments in children because many of the best students leave the community upon graduation from high school. This situation creates a disincentive for rural communities because urban and suburban areas benefit from their investments (Hobbs 1995; Lichter et al. 1993). As one anonymous reviewer noted, many communities choose to invest in the education of their youth anyway. This might be because residents place a high value on education or perceive that retaining some well-educated youth is better than having all youth with low educational attainment.
} 


\subsubsection{Family Social Capital}

Structural characteristics of the family that can influence the emergence of social capital include the presence of one or both parents in the home and the number of siblings. These factors dictate the opportunity for interpersonal interactions to occur between parents and children and shape the frequency and duration of such interactions (Smith, Beaulieu, and Seraphine 1995). Intact families have a positive influence on the academic success of their children (Bogenschneider 1997; Coleman 1990), while the presence of many siblings can dilute the amount of time that parents can devote to any single child (Blake 1981; Downey 1995).

The process aspects of family social capital are demonstrated by the quality of parents' involvement in the lives of their children. These include parents' nurturing activities, such as helping children with their homework, discussing important school activities with them, and expressing high educational aspirations for them (Downey 1995; Teachman, Paasch, and Carver 1997). It also includes sponsoring and participating in other activities that help develop a child's competence and confidence.

Process features of family social capital also include constraining activities, such as limiting television viewing, providing adult supervision when the children return from school, and monitoring homework (McNeal 1999). Though constraining activities are a necessary part of child rearing, relationships that are abusive or neglectful can erect barriers to educational achievement.

\subsubsection{School Social Capital}

Structural components of schools that can impact the quality of social capital include the socioeconomic and demographic background of the student population, the number of students enrolled in the school, and the nature of the learning climate in the school or classroom (Stockard and Mayberry 1992).

Students in schools whose enrollment is drawn primarily from high socioeconomic status families and who interact with high-status peers, have higher achievement on average, in part because students attending higher SES schools are more likely to establish friendships with individuals having good learning skills and high educational aspirations (Stockard and Mayberry 1992; Blau 1960; Coleman et al. 1966). At the same time, higher status schools are likely to have well-articulated norms and values that encourage good academic performance and limit problem behaviors (Alexander and Eckland 1975; Friedkin and Neocochea 1988; Hoffer, Greeley, and Coleman 1987; Rutter et al. 1979).

Closely linked to the socioeconomic context of the school is race and ethnicity. Schools comprised mainly of white students are more likely to be drawn from middleclass areas, while those that are more racially and ethnically diverse are more likely to be drawn from lower socioeconomic status families and neighborhoods (Stockard and Mayberry 1992). 
School size (number of enrolled students) is commonly linked to student achievement. To some, larger schools promote higher achievement since they can offer students a richer set of course offerings, have better trained and qualified teachers, and have a more diverse set of educational support services (Ballou and Podgursky 1998; Greenberg and Teixeira 1998). Others argue that smaller schools are better academically because of lower student-teacher ratios, the greater attention by teachers to the needs of their students, the higher rates of participation in school activities, and the lower rates of absenteeism (Greenwald, Hedges, and Laine 1996; Gregory and Smith 1987; Hobbs 1995; Lee and Smith 1996; Rossi and Daugherty 1996; Sher 1988; Walberg and Fowler 1987).

Among the process components of school social capital is the active engagement of teachers and parents in the lives of students (Hoffer, Greeley, and Coleman 1987; Lee and Smith 1996; Rutter et al. 1979). Relevant activities include teachers' interest in the welfare of students through positive teacher/student interactions and efforts to engage students in school programs and activities that help integrate them into the life of the school (Flinn and Rock 1997). Students who perceive teachers as having a caring attitude and who see these individuals as role models are more inclined to want to succeed in school (Noddings 1988; Werner and Smith 1989).

Students whose parents are involved in their school, through parent-teacher organizations and booster groups, perform better in their academic courses and are less likely to drop out of high school (Eccles and Harold 1993; McNeal 1999; Parcel and Dufur 2001; Stevenson and Baker 1987; Walberg 1984). While many activities are nurturing, others serve to constrain undesirable behavior. Thus, parental contact with teachers or school administrators and between teachers and students concerning academic or behavioral concerns can indicate academic difficulties and lower achievement (McNeal 1999).

\subsubsection{Community Social Capital}

Localities with high community social capital are marked by extensive civic engagement and patterns of mutual support (Putnam 2000; Wilkinson 1991). ${ }^{2}$ Community activeness builds social capital since the network of relationships that develop from past local activities can be tapped whenever new efforts to address educational or other community needs are initiated (Zekeri, Wilkinson, and Humphrey 1994). Structural features of a community that can boost the creation and accumulation of social capital include proximity, stability, and equality (Israel, Beaulieu, and Hartless 2001). Physical proximity increases opportunities for interactions among local residents that build community bonds. Residents living in the sparsely populated rural countryside incur the added cost of space in maintaining social networks, especially the "weak ties" comprised of more transitory interactions that underpin much of community interaction (Granovetter 1973; Wilkinson 1991).

\footnotetext{
${ }^{2}$ Social capital also can accumulate within any local group or organization and thus can be used to further the private interests of that group, sometimes to the detriment of other groups in the community (see Flora 1998; Wall, Ferrazzi, and Schryer 1998).
} 
Residential stability contributes to the emergence of strong local links because communities with low residential turnover have ample opportunities to develop relationships that can be used to coordinate community improvement activities and to build community social capital (Putnam 2000). With regard to education, children who move frequently have relationships disrupted at each instance and are hampered in establishing long-term relationships with individuals in the community (Smith, Beaulieu, and Seraphine 1995).

Finally, equality can reduce social divisions that affect the quality of interaction (Blau 1994). Insofar as certain racial or ethnic minorities have less access to a locality's resources, such disparities can become the basis for durable cleavages between a community's elites and disadvantaged groups, particularly when local priorities are being determined. When residents feel alienated, participation in local affairs declines and collective action is fragmented. One outcome of high inequality is that less social capital is available to improve local education.

The process components of community social capital can be demonstrated by the level of interest and caring that adult members of the community have for the welfare of each other's children and by the efforts of individuals and organizations to engage children in community programs and activities that make effective use of their time and energy (Coleman and Hoffer 1987; Smith, Beaulieu, and Seraphine 1995). When these activities involve adults with higher levels of educational attainment, youth are immersed in an environment that encourages educational achievement.

\section{METHODOLOGY}

The analysis is based on data collected as part of the National Educational Longitudinal Study (NELS) conducted by the National Opinion Research Center for the National Center for Education Statistics. The initial survey, conducted in 1988, involved a stratified national probability sample of more than 1,052 schools ( 815 were public schools). A sample of $8^{\text {th }}$ grade pupils was surveyed from each of these schools, yielding a total of 24,599 usable responses. Students provided information on individual and family characteristics, school experiences, participation in extracurricular activities, and future plans. Linked to the student surveys were nearly 22,700 parent surveys with information on family characteristics, parents' views of their children's school experiences, and expectations for their children.

Data from the School District Data Book (SDDB) and the Common Core of Data (CCD) files developed by the National Center for Education Statistics were linked with the privileged version of the NELS data. ${ }^{3}$ We merged 1990 census data describing community structural attributes with the 1988 NELS data. Finally, we incorporated county typology codes from the Economic Research Service and voter participation data

\footnotetext{
${ }^{3}$ The privileged version includes geographic codes that are not available in the public data. These codes allow school district and county census data from other sources to be combined with the NELS data.
} 
from the Inter-University Consortium for Political and Social Research. Though the overlap and hierarchy of school, school district, and county differ across states, we treated these variables as a single level in our analysis.

This study was limited to students in public schools with at least 10 students surveyed with usable data. After selecting students having full data on the variables of interest, the analysis included 9,199 students enrolled in 687 public schools in the $8^{\text {th }}$ grade. The number of students included in our analysis of gains scores over the $8^{\text {th }}$ to $12^{\text {th }}$ grades declined to 5,612 due to attrition. To minimize problems with the decline in sample, we used weights to ensure the representativeness of the various sub-populations engaged in this study (Ingels et al. 1998).

\subsection{Measurement of Variables}

Increasingly, achievement in primary and secondary school is linked to students' progress as measured by school-administered standardized exams (Amrein and Berliner 2002; Kohn 2000). While the validity and meaning of such test scores continues to be hotly debated, there is little question that their greatly expanded use is changing contemporary education policies and practice. Five dependent variables are employed in our analysis. Three were $8^{\text {th }}$ grade test scores: the math/reading composite, math IRT test score, and reading IRT test score. The remaining two examined math and reading gain scores between the $8^{\text {th }}$ and $12^{\text {th }}$ grades. $^{4}$

The first dimension of our model includes independent variables that were designed to capture the students' innate capabilities and other background factors. Race and gender variables are included because blacks are more likely than whites to leave school and females are less likely to attend college (Ekstrom et al. 1986; Smith, Beaulieu, and Seraphine 1995). To capture the intellectual abilities of each child and the child's engagement in learning, we add six variables to the model - whether the student is classified as gifted; the child's grade point average in middle school; the student's readiness for class; hours spent doing homework during the week; student engagement in the classroom (based on teacher's ratings); and student's interest in, and expected future value of, math and English. These, along with taking advanced courses (Algebra 1), high attendance (based on incidence of tardiness, skipping, and being absent), and disruptive behavior in the classroom (measured from the teacher's perspective), were seen as factors that would likely affect academic success.

The next major dimension of the model includes variables for the level of resources available to students in their homes, schools, and communities. Certainly, children from higher socioeconomic status families are likely to do better academically because of the more diverse set of resources that can be tapped to facilitate learning (Coleman et al.

\footnotetext{
${ }^{4}$ The gain scores are based on the difference between IRT test score for each grade and subject. Details about the variables and coding scheme employed for this study are available from the senior author.
} 
1966; U.S. Department of Education 2003). To capture this aspect of the family, we include two key variables in our analysis - family income and whether one or more parents had a college education.

To assess the level of financial assets made available to support the educational activities of schools, we incorporate "core school expenditures on a per student basis" into our model. While past studies have been inconclusive, there is some evidence that higher per student expenditures can have a positive impact on student achievement (Greenwald, Hedges, and Laine 1996). At the community level, we capture local socioeconomic capacity through the use of a county-level composite measure based on six interrelated items: poverty rate, median income, employment diversity, concentration of wealth, percent of unemployed households, and the mean level of education.

The final dimension of our model is the set of structural and process social capital attributes of the students' families, schools, and communities. Within the context of the home, we focus on two structural measures: parental structure (i.e., the presence or absence of both parents in the home) and the number of siblings. The process aspects of family social capital are captured by five variables: nurturing activities (parents express expectations to the child about attending college; child discusses school matters with parents) and monitoring activities (how much parents limit TV viewing, how often parents check the child's homework, and the amount of time that the child is home alone after school). These variables have shown strong effects on educational outcomes in earlier studies (Beaulieu et al. 2001; Downey 1995; Israel, Beaulieu, and Hartless 2001; McNeal 1999; Smith, Beaulieu, and Seraphine 1995; Teachman, Paasch, and Carver 1997).

Several structural measures of school social capital are included: the number of students enrolled in the school, the school's minority percentage, the percent of students enrolled in the free and reduced price lunch program, average daily attendance rate, and school climate. A four-item index measuring a school's dedication to academic excellence serves as our proxy for school climate. The size of the student body, its demographic and economic characteristics, and the school's commitment to academics represent important factors that can influence educational aspirations and expectations of students (Friedkin and Neocochea 1988; Stockard and Mayberry 1992).

Three process measures of school social capital are used to measure the extent of a student's social integration in the school. These include the number of organizations in which students are involved, the amount of discussion between students and their teachers outside of class, and the extent to which students view their teachers as nurturing individuals. Students actively involved in school organizations tend to thrive academically (Flinn and Rock 1997), while those requiring frequent monitoring and corrective instructions are less inclined to stay in school.

Three additional school social capital attributes included in our model are parental involvement in the school's parent-teacher organization (PTO), parents' participation in 
other school organizations, and frequency of parental contacts with the school on matters associated with academics, discipline, fund raising, and so on.

Following Israel, Beaulieu, and Hartless (2001), the structural attributes of the community include measures of proximity, stability, and equality. Proximity is measured with a county typology (metro core, other metro, adjacent nonmetro, and nonadjacent nonmetro) (Butler and Beale 1994) and the percent of residents who commute to work outside the county. Stability was measured in two ways: by the mean number of years householders in a county have lived in their current place of residence, and by the percent of the population living in the same home as five years earlier.

The process features of community social capital focus on the student's level of social integration in the community. ${ }^{5}$ Five process measures are included in our model: the number of times a student had changed schools since first grade, the student's participation in religious activities, the number of community organizations in which the student has been involved, the number of leadership positions held, and how many parents of friends that their own parents tend to know. ${ }^{6}$ Children who experience frequent moves are at greater risk of dropping out of school, while those who participate in religious or nonreligious organizations are more inclined to stay in school (Coleman 1988; Israel, Beaulieu, and Hartless 2001; Teachman, Paasch, and Carver 1997). Furthermore, when other parents or local adults know these students, the adults can serve as a support system outside of the family or school that can guide and monitor youths' activities (Coleman 1988).

\subsection{Analysis}

To make inferences about U.S. public schools and their students, we employ hierarchical linear models (HLM) to examine students' $8^{\text {th }}$ grade test scores and $8^{\text {th }}-12^{\text {th }}$ grade gain scores for math and reading. We also used the $8^{\text {th }}$ grade IRT test score as a control variable in the gain score models (see Morgan and Sørensen 1999). Each model was specified to estimate parameters for two levels: student and school/community, with students nested within the school/community context. The models are also intended to clearly delineate the role of community proximity in the central place hierarchy (e.g., metro core, other metro, etc.) in shaping educational achievement. Community proximity serves as a mediating variable in our analysis, since family, school, and community attributes vary across geographic areas.

\footnotetext{
${ }^{5}$ Measures of community-wide social networks were not available.

${ }^{6}$ We assumed that participation in religious and non-religious groups involved youth in relationships with adults and peers. Information about the quality of these relationships was not available (Carbonaro 1999).
} 
TABLE 1

Mean Math and Reading Test Scores for Students by County Type

\begin{tabular}{lcccc}
\hline & $\begin{array}{c}\text { Metro } \\
\text { Core } \\
(\mathrm{n}=3,202)\end{array}$ & $\begin{array}{c}\text { Other } \\
\text { Metro } \\
(\mathrm{n}=3,449)\end{array}$ & $\begin{array}{c}\text { Adjacent } \\
\text { Nonmetro } \\
(\mathrm{n}=1,320)\end{array}$ & $\begin{array}{c}\text { Nonadjacent } \\
\text { Nonmetro } \\
(\mathrm{n}=1,228)\end{array}$ \\
\hline 8th grade math/reading composite score & 51.980 & 51.743 & 50.736 & 51.537 \\
& 45.973 & 45.536 & 44.789 & 45.456 \\
8th grade math IRT score & 8.879 & 8.612 & 7.945 & 8.073 \\
8th to 12th grade math IRT gain score & 46.753 & 46.922 & 46.243 & 46.761 \\
8th grade reading IRT score & 6.686 & 5.793 & 5.709 & 5.604 \\
8th to 12th grade reading IRT gain score & & & & \\
\hline
\end{tabular}

\section{RESULTS}

Test scores for $8^{\text {th }}$ graders show few differences across the county types, though there was a downward trend from students living in metro core to those in nonadjacent nonmetro counties for the composite score (Table 1). Differences emerged in the $8^{\text {th }}$ to $12^{\text {th }}$ grade gain scores, with metro core and metro other having larger math IRT gains and metro core having larger reading IRT gains.

Though the county typology differences in test outcomes are modest, those for student, school, and community attributes are large in many cases. A sampling of these variations can be seen in Tables 2 and 3. Table 2 presents mean scores on all studentlevel variables across the four county types, while Table 3 provides mean data for school/ community based measures. Differences across the four geographic areas will be reviewed in greater depth in the discussion section of our study.

Table 4 reveals that a large number of variables were significant predictors of $8^{\text {th }}$ grade math, reading, and the math/reading composite test scores. Of the student abilities and background variables, the two measures of ability (gifted status and grade point average) and taking Algebra 1 were especially important. Most measures of student engagement were significant. Hours spent doing homework and engagement in the classroom had a positive net effect on all three $8^{\text {th }}$ grade test scores. The magnitude of these effects over the range of possible values is on par with taking Algebra 1. Interest in math and English classes was inconsistent, while readiness for class had a negative affect after controlling for other variables. Students who were rated by their teachers as being disruptive and those with poor attendance also scored lower on the tests. Finally, the disadvantages seen for females in math and for minorities in all tests remain after other variables are included.

The results are consistent with previous status attainment research that has shown that family resources affect educational achievement. For example, children whose mother or father attended college were more likely to have higher test scores. Likewise, 
TABLE 2

Mean of Student-level Variables by County Type

\begin{tabular}{|c|c|c|c|c|}
\hline & $\begin{array}{c}\text { Metro Core } \\
(\mathrm{n}=3,202)\end{array}$ & $\begin{array}{l}\text { Other Metro } \\
(\mathrm{n}=3,449)\end{array}$ & $\begin{array}{l}\text { Adjacent Nonmetro } \\
(\mathrm{n}=1,320)\end{array}$ & $\begin{array}{c}\text { Nonadjacent Nonmetro } \\
(\mathrm{n}=1,228)\end{array}$ \\
\hline \multicolumn{5}{|l|}{ Student Abilities and Background } \\
\hline Gender (\% female) & 52.000 & 51.700 & 54.300 & 51.200 \\
\hline Race (\% white) & 72.100 & 82.800 & 85.800 & 87.500 \\
\hline Student classified as gifted (\%) & 19.400 & 14.500 & 10.500 & 10.600 \\
\hline Average grades composite $(\mathrm{A}=4.0)$ & 2.987 & 2.969 & 3.041 & 3.008 \\
\hline Student had Algebra 1 in 8 th grade (\%) & 40.300 & 36.800 & 35.500 & 28.600 \\
\hline Student regarded as disruptive in class (\%) & 13.400 & 12.600 & 9.500 & 9.600 \\
\hline Student skips, is tardy or absent (index max $=10$ ) & 1.568 & 1.388 & 1.322 & 1.155 \\
\hline Student's readiness for class (index max $=9$ ) & 6.285 & 6.329 & 6.464 & 6.591 \\
\hline Teacher's rating of student engagement (index max $=3$ ) & 2.348 & 2.358 & 2.515 & 2.473 \\
\hline Students' interest in class \& future value (index max $=3$ ) & 1.896 & 1.868 & 1.940 & 1.899 \\
\hline Hours doing homework per subject per week & 1.672 & 1.649 & 1.594 & 1.672 \\
\hline \multicolumn{5}{|l|}{ Resources } \\
\hline At least 1 parent attended college (\%) & 76.100 & 72.800 & 64.000 & 67.500 \\
\hline Family income (group mean centered) & 1.405 & 1.246 & 1.273 & 1.483 \\
\hline \multicolumn{5}{|l|}{ Family Social Capital Structure } \\
\hline Number of siblings & 2.201 & 2.175 & 2.179 & 2.275 \\
\hline Two-parent families (\%) & 78.900 & 81.200 & 82.000 & 81.300 \\
\hline \multicolumn{5}{|l|}{ Family Social Capital Process } \\
\hline How often parents discuss school with child (index $\max =2$ ) & 1.402 & 1.417 & 1.401 & 1.422 \\
\hline Amount of time spent alone after school $($ index $\max =4)$ & 1.837 & 1.864 & 1.803 & 1.785 \\
\hline How often parents check child's homework (often $=3$ ) & 2.104 & 2.073 & 1.985 & 2.071 \\
\hline How much parents limit TV time (often $=3$ ) & 1.154 & 1.112 & 1.024 & 1.034 \\
\hline $\begin{array}{l}\text { How far parent expects child to go in school (complete } \\
\text { graduate degree = 4) }\end{array}$ & 2.826 & 2.675 & 2.619 & 2.570 \\
\hline
\end{tabular}


TABLE 2 (Continued)

\begin{tabular}{|c|c|c|c|c|}
\hline & $\begin{array}{c}\text { Metro Core } \\
(n=3,202)\end{array}$ & $\begin{array}{c}\text { Other Metro } \\
(n=3,449)\end{array}$ & $\begin{array}{c}\text { Adjacent Nonmetro } \\
(n=1,320)\end{array}$ & $\begin{array}{l}\text { Nonadjacent Nonmetro } \\
(\mathrm{n}=1,228)\end{array}$ \\
\hline \multicolumn{5}{|l|}{ School Social Capital Process } \\
\hline Student talks to teacher outside class (index max $=5$ ) & 2.329 & 2.261 & 2.521 & 2.213 \\
\hline Teacher is nurturing to student (index $\max =3.3$ ) & 2.132 & 2.096 & 2.156 & 2.138 \\
\hline No. of school orgs. involved in & 2.905 & 2.909 & 3.408 & 3.151 \\
\hline Average amount that parents contact school $(4+$ times $=3)$ & .405 & .392 & .350 & .350 \\
\hline Parent involved with other school organizations (\%) & 24.700 & 26.000 & 28.100 & 28.400 \\
\hline Amount of parent's volunteering in PTO (index max = 4) & 1.128 & .965 & .867 & .817 \\
\hline \multicolumn{5}{|l|}{ Community Social Capital Process } \\
\hline Student belongs to religious group (\%) & 32.900 & 34.900 & 40.800 & 41.700 \\
\hline Number of nonreligious groups student involved in & 1.289 & 1.317 & 1.387 & 1.295 \\
\hline Number of leadership positions held in community & .738 & .736 & .764 & .768 \\
\hline Number of times changed school since grade 1 & 1.358 & 1.322 & .992 & .958 \\
\hline Parent knows name of child's friends parents $(\max =5)$ & 2.541 & 2.757 & 3.017 & 3.178 \\
\hline
\end{tabular}


TABLE 3

Mean of Schools' Characteristics by County Type

\begin{tabular}{|c|c|c|c|c|}
\hline & $\begin{array}{c}\text { Metro } \\
\text { Core } \\
(\mathrm{n}=256) \\
\end{array}$ & $\begin{array}{c}\text { Other } \\
\text { Metro } \\
(\mathrm{n}=252) \\
\end{array}$ & $\begin{array}{c}\text { Adjacent } \\
\text { Nonmetro } \\
(\mathrm{n}=93)\end{array}$ & $\begin{array}{c}\text { Nonadjacent } \\
\text { Nonmetro } \\
(\mathrm{n}=86)\end{array}$ \\
\hline \multicolumn{5}{|l|}{ Resources } \\
\hline Per pupil expenditures & $\$ 3,545$ & $\$ 2,998$ & $\$ 2,730$ & $\$ 2,628$ \\
\hline Socio-economic capacity (index centered on 0 ) & 0.279 & 0.030 & -0.482 & -0.704 \\
\hline \multicolumn{5}{|l|}{ School Social Capital Structure } \\
\hline School enrollment & 881 & 737 & 566 & 504 \\
\hline Percent minority students in school & 40.9 & 21.6 & 20.6 & 16.2 \\
\hline Percent free lunch in school & 29.8 & 23.5 & 27.7 & 32.9 \\
\hline $\begin{array}{l}\text { Emphasis on academics (aggregate of parents' } \\
\text { perceptions for } 4 \text { items, index range } 0 \text { to } 3 \text { ) }\end{array}$ & 2.036 & 2.000 & 1.964 & 1.996 \\
\hline Average attendance rate (\%) & 92.7 & 93.7 & 94.3 & 94.1 \\
\hline \multicolumn{5}{|l|}{ Community Social Capital Structure } \\
\hline Percent of employed who work outside county & 23.7 & 22.4 & 29.3 & 16.7 \\
\hline Percent of people in same county in 1985 & 79.6 & 79.3 & 81.5 & 83.0 \\
\hline Average years of living in the home & 10.1 & 10.8 & 12.0 & 11.8 \\
\hline Percent of registered voting in 1988 & 72.6 & 71.3 & 68.4 & 67.7 \\
\hline Average population in 1990 & 761,379 & 104,899 & 24,713 & 19,861 \\
\hline
\end{tabular}


TABLE 4

Regression Coefficients Showing the Effect of Social Capital on $8^{\text {th }}$ Grade Test Scores

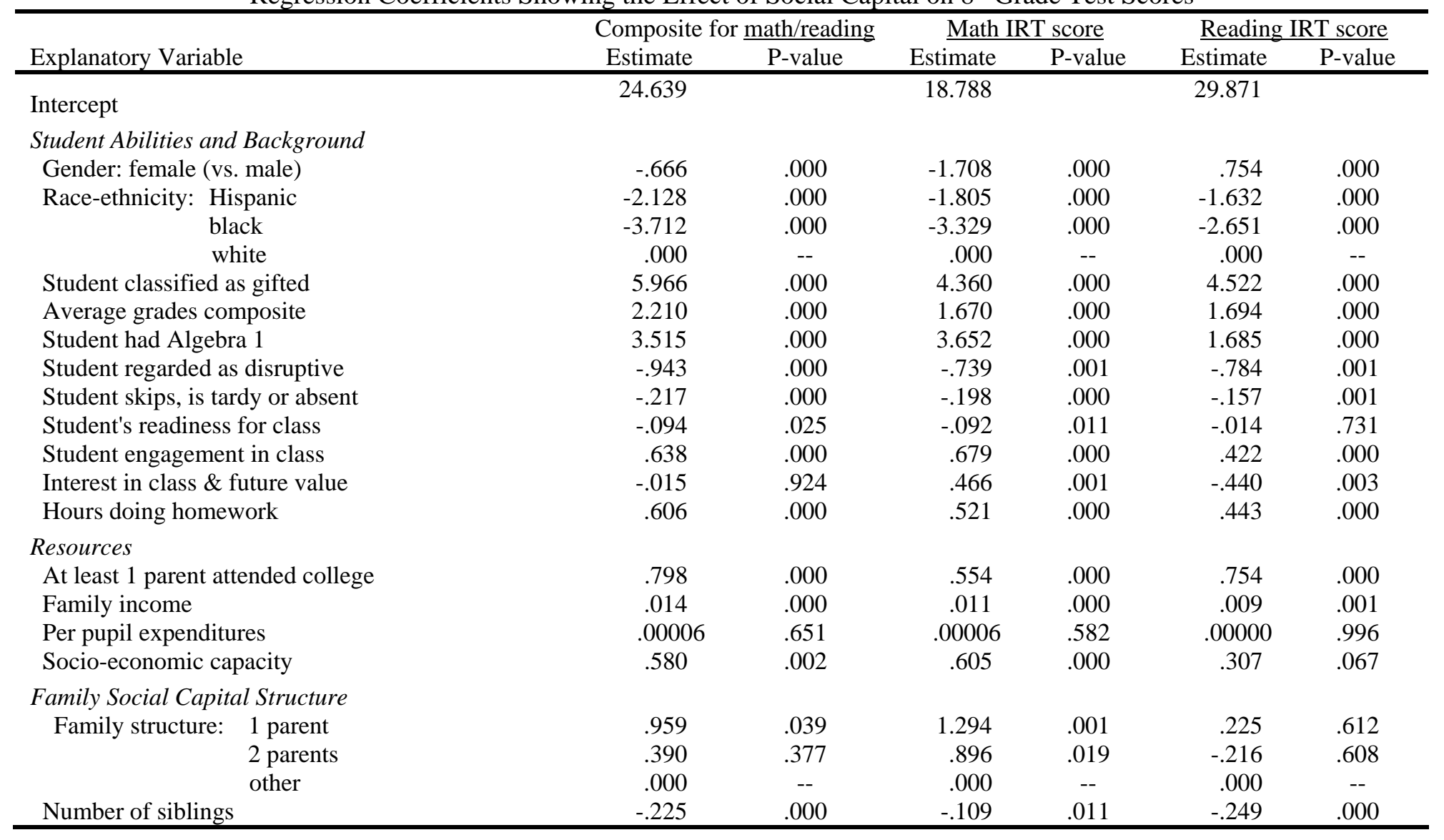


TABLE 4 (Continued)

\begin{tabular}{|c|c|c|c|c|c|c|}
\hline \multirow[b]{2}{*}{ Explanatory Variable } & \multicolumn{2}{|c|}{ Composite for math/reading } & \multicolumn{2}{|c|}{ Math IRT score } & \multicolumn{2}{|c|}{ Reading IRT score } \\
\hline & Estimate & P-value & Estimate & P-value & Estimate & P-value \\
\hline \multicolumn{7}{|l|}{ Family Social Capital Process } \\
\hline How often parents/child discuss & 2.000 & .000 & 1.334 & .000 & 1.917 & .000 \\
\hline Amount of time spent alone & -.198 & .001 & -.159 & .000 & -.146 & .014 \\
\hline How often parents check homework & -.681 & .000 & -.543 & .000 & -.513 & .000 \\
\hline How much parents limit tv time & .391 & .000 & .285 & .000 & .322 & .000 \\
\hline How far parent expects child to go & 1.649 & .000 & 1.316 & .000 & 1.309 & .000 \\
\hline \multicolumn{7}{|l|}{ School Social Capital Structure } \\
\hline Emphasis on academics & 2.224 & .000 & 3.128 & .000 & .440 & .422 \\
\hline Minority percent of enrolled & -.019 & .000 & -.017 & .000 & -.013 & .006 \\
\hline Percent in free \& reduced lunch & -.026 & .000 & -.024 & .000 & -.015 & .015 \\
\hline School enrollment & .00006 & .848 & .00006 & .833 & .00000 & .977 \\
\hline Average student attendance rate & .118 & .000 & .117 & .000 & .076 & .008 \\
\hline \multicolumn{7}{|l|}{ School Social Capital Process } \\
\hline Talks to teacher outside class & -.371 & .000 & -.260 & .000 & -.329 & .000 \\
\hline Teacher is nurturing to student & -.296 & .032 & -.428 & .000 & -.135 & .306 \\
\hline No. of school orgs. involved in & -.112 & .000 & -.072 & .008 & -.138 & .000 \\
\hline Amount that parents contact school & -.667 & .001 & -.613 & .000 & -.485 & .012 \\
\hline Parent involved with other school organizations & .326 & .075 & .318 & .045 & .157 & .371 \\
\hline Amt. parent's volunteer for PTO & -.152 & .026 & -.173 & .004 & -.062 & .344 \\
\hline \multicolumn{7}{|l|}{ Community Social Capital Structure } \\
\hline Residential stability & -.067 & .001 & -.048 & .008 & -.054 & .002 \\
\hline Residential longevity & .238 & .002 & .158 & .021 & .208 & .002 \\
\hline \multirow[t]{5}{*}{ Percent commuting: me } & -.026 & .000 & -.024 & .000 & -.017 & .011 \\
\hline & -.031 & .001 & -.032 & .000 & -.015 & .022 \\
\hline & -.032 & .005 & .028 & .002 & -.020 & .047 \\
\hline & -.004 & .830 & .002 & .907 & -.008 & .615 \\
\hline & .023 & .047 & .017 & .102 & .017 & .091 \\
\hline
\end{tabular}


TABLE 4 (Continued)

\begin{tabular}{|c|c|c|c|c|c|c|}
\hline \multirow[b]{2}{*}{ Explanatory Variable } & \multicolumn{2}{|c|}{ Composite for math/reading } & \multicolumn{2}{|c|}{ Math IRT score } & \multicolumn{2}{|c|}{ Reading IRT score } \\
\hline & Estimate & P-value & Estimate & P-value & Estimate & P-value \\
\hline \multicolumn{7}{|l|}{ Community Social Capital Process } \\
\hline Student belongs to religious group & 1.305 & .000 & .724 & .000 & 1.222 & .000 \\
\hline Number of nonreligious groups student involved in & -.507 & .000 & -.347 & .000 & -.416 & .000 \\
\hline Number of leadership positions & .822 & .000 & .592 & .003 & .766 & .000 \\
\hline No. of times changed school & -.012 & .000 & -.027 & .526 & .010 & .839 \\
\hline Parent knows child's friends parents & -.063 & .805 & -.027 & .531 & -.062 & .190 \\
\hline
\end{tabular}


test scores tended to be higher among children from families with higher incomes, though this was modest in comparison to family social capital variables. School resources, as measured by per student expenditures, had little effect on test scores. Community resources (i.e., socioeconomic capacity), however, showed a modest and positive net influence on test scores.

In keeping with earlier research on the structural aspect of family social capital (Beaulieu and Israel 1997; Israel, Beaulieu, and Hartless 2001; Smith, Beaulieu, and Seraphine 1995), family structure had some influence on test scores. The presence of one parent in the household was associated with higher test scores on two of the three measures. In addition, students with one or more siblings were less likely to do well on the $8^{\text {th }}$ grade tests.

Family social capital appears important in shaping a child's academic performance. We found that students were more likely to have higher test scores if a parent expressed expectations for obtaining a college degree (as compared to a high school diploma or not completing high school), if they discussed school programs with their parents, if parents placed limits on the amount of time that the child was allowed to watch television, if parents did not have to check homework frequently, and their $8^{\text {th }}$ grader spent little or no time alone after school.

The role of school structure in helping young people perform well on tests is significant for a number of measures. The number of students enrolled in the school was not a significant factor, but the percentage of minority students and those in the free lunch program had a significant negative effect. Schools having an emphasis on academic achievement increased students' test scores, though this effect was much smaller for reading. Higher attendance rates also were associated with higher test scores for students at those schools.

Regarding the social capital process variables, the frequency of teacher-student conversations outside the classroom negatively affected test scores. This might mean that after accounting for ability and engagement, students who need to talk with teachers outside of class do so to address an academic or behavioral problem. Surprisingly, having teachers who are more nurturing and the degree of involvement in student organizations had a negative effect on test scores, but the impact was small.

Several other school social capital variables were significant. Students whose parents were involve in a PTO scored lower on the tests, but those with parents involved in other school organizations did better on the tests (though marginally significant). This might reflect a more ritualistic involvement in PTOs, as compared to the intensive involvement of parents in sports or band booster organizations. It is likely that this type of parental involvement fosters student-parent and teacher-parent relationships and helps the student stay engaged in school. On the other hand, in cases where the parent contacted the school, these interactions had a negative effect on test scores, likely reflecting instances where parental contacts were precipitated by disciplinary or academic problems. 
Results for community structure in Table 4 show modest effects on test scores. Average years in the current home had a positive effect on test scores. Communities having higher residential stability and a lower percentage of commuters also showed a positive association with test scores. ${ }^{7}$ The county type, which indicates community proximity in the central place hierarchy, moderates the effect of other community and school attributes and, more importantly, remains a significant factor in our models.

Three process measures of community social capital were influential on test scores. Involving youth in a religious group had a positive effect, but participating in other youth organizations lowered test scores. Taking on a leadership role in these organizations had a positive effect, which suggests that a more in-depth mentor-protégé relationship is necessary for the student to benefit. The number of times a student has changed schools and parents knowing other parents were not important, in most cases, after the effects of other variables were taken into account.

Overall, the results in Table 4 suggest that many social capital variables, as well as those measuring student activities and ability, have significant effects on $8^{\text {th }}$ grade test scores. The results also suggest that these are additive in the same way that the Search Institute's asset model (Scales and Roehlkepartain 2003) posits that the more positive factors (or assets) that a student has, the more resilient and successful the student will be. Similar but less dramatic results are shown for estimated gain scores in Table 5. Of the notable differences, gender had nearly as large an effect on gains scores as for the base year, and having a parent attend college also maintained its effect. On the other hand, behaviors inhibiting (being disruptive, tardy, or absent) or facilitating learning (hours doing homework) had less impact on gains. This might reflect the fact that many low performing students drop out of school between the $8^{\text {th }}$ and $12^{\text {th }}$ grades.

As the results in Tables 4 and 5 suggest, the variables included in our analysis form a powerful set of predictors for student's scores on $8^{\text {th }}$ grade standardized tests and on subsequent gains when viewed collectively. The R-squares for $8^{\text {th }}$ grade math and reading IRT test scores range from .321 to .537 (Table 6). Review of the reduction in unexplained variance for the two models shows that student ability and background variables have large impacts, followed by family social capital structure and process variables. Resources, mostly at the family level, had nearly the impact of family social capital.

School and community social capital variables reduced unexplained variance by a modest amount, and these were larger for students living in nonmetro counties (both adjacent and nonadjacent). It also appears that the contextual effect of school and community is interrelated with student variables, so that the school/community variance was reduced as student-level variables were added to the model. The R-squares for math and reading gain scores (between $8^{\text {th }}$ and $12^{\text {th }}$ grades) were modest and ranged from .058 to .170 (Table 7). The pattern of effects shown in Table 6 (e.g., student abilities and

${ }^{7}$ Commuting in nonadjacent nonmetro communities is not significant because there is less commuting (also, less variation) among these counties. 
background having the largest reduction in unexplained variance, followed by family social capital) was also seen for math and reading gain score variances shown in Table 7.

TABLE 5

Regression Coefficients Showing the Effect of Social Capital on Gain Scores

\begin{tabular}{|c|c|c|c|c|}
\hline \multirow[b]{2}{*}{ Explanatory Variable } & \multicolumn{2}{|c|}{$\begin{array}{l}8^{\text {th }}-12^{\text {th }} \\
\text { Math Gain }\end{array}$} & \multicolumn{2}{|c|}{$\begin{array}{c}8^{\text {th }}-12^{\text {th }} \\
\text { Reading Gain }\end{array}$} \\
\hline & Estimate & P-value & Estimate & P-value \\
\hline Intercept & 9.229 & & 11.109 & \\
\hline $\begin{array}{l}\text { Base-year control } \\
8^{\text {th }} \text { Grade test score }\end{array}$ & -.207 & .000 & -.270 & .000 \\
\hline $\begin{array}{l}\text { Student Abilities and Background } \\
\text { Gender: female (vs. male) } \\
\text { Race-ethnicity: } \quad \text { Hispanic } \\
\text { black } \\
\text { white } \\
\text { Student classified as gifted } \\
\text { Average grades composite } \\
\text { Student had Algebra } 1 \\
\text { Student regarded as disruptive } \\
\text { Student skips, is tardy or absent } \\
\text { Student's readiness for class } \\
\text { Student engagement in class } \\
\text { Interest in class \& future value } \\
\text { Hours doing homework }\end{array}$ & $\begin{array}{r}-1.326 \\
-.790 \\
-1.055 \\
.000 \\
1.161 \\
1.092 \\
.710 \\
-.054 \\
-.121 \\
.004 \\
.366 \\
.574 \\
.022\end{array}$ & $\begin{array}{c}.000 \\
.001 \\
.000 \\
-- \\
.000 \\
.000 \\
.000 \\
.834 \\
.021 \\
.930 \\
.000 \\
.000 \\
.755\end{array}$ & $\begin{array}{r}.623 \\
-1.011 \\
-2.145 \\
.000 \\
1.421 \\
.873 \\
1.105 \\
-.042 \\
.002 \\
-.073 \\
.255 \\
-.115 \\
.132\end{array}$ & $\begin{array}{c}.001 \\
.018 \\
.000 \\
-- \\
.000 \\
.000 \\
.000 \\
.902 \\
.976 \\
.178 \\
.029 \\
.561 \\
.145\end{array}$ \\
\hline $\begin{array}{l}\text { Resources } \\
\text { At least } 1 \text { parent attended college } \\
\text { Family income } \\
\text { Per pupil expenditures } \\
\text { Socio-economic capacity }\end{array}$ & $\begin{array}{l}.570 \\
.006 \\
.0002 \\
.415\end{array}$ & $\begin{array}{l}.001 \\
.032 \\
.081 \\
.015\end{array}$ & $\begin{array}{l}.358 \\
-.003 \\
.0001 \\
-.030\end{array}$ & $\begin{array}{l}.115 \\
.367 \\
.373 \\
.888\end{array}$ \\
\hline $\begin{array}{cc}\text { Family Social Capital } & \text { Structure } \\
\text { Family structure: } & 1 \text { parent } \\
& 2 \text { parents } \\
& \text { other } \\
\text { Number of siblings } & \end{array}$ & $\begin{array}{r}.125 \\
.151 \\
.000 \\
-.061\end{array}$ & $\begin{array}{c}.803 \\
.752 \\
-- \\
.208\end{array}$ & $\begin{array}{r}2.070 \\
2.060 \\
.000 \\
-.133\end{array}$ & $\begin{array}{c}.002 \\
.001 \\
-- \\
.037\end{array}$ \\
\hline $\begin{array}{l}\text { Family Social Capital Process } \\
\text { How often parents/child discuss } \\
\text { Amount of time spent alone } \\
\text { How often parents check homework } \\
\text { How much parents limit tv time } \\
\text { How far parent expects child to go }\end{array}$ & $\begin{array}{r}.111 \\
-.141 \\
-.238 \\
.147 \\
.794\end{array}$ & $\begin{array}{l}.515 \\
.020 \\
.001 \\
.036 \\
.000\end{array}$ & $\begin{array}{r}.135 \\
-.026 \\
-.227 \\
.264 \\
1.016\end{array}$ & $\begin{array}{l}.545 \\
.747 \\
.019 \\
.004 \\
.000\end{array}$ \\
\hline
\end{tabular}


TABLE 5 (Continued)

\begin{tabular}{lcccc}
\hline & \multicolumn{2}{c}{$8^{\text {th }}-12^{\text {th }}$} & \multicolumn{2}{c}{$8^{\text {th }}-12^{\text {th }}$} \\
Math Gain & \multicolumn{2}{c}{ Reading Gain } \\
Explanatory Variable & Estimate & P-value & Estimate & P-value \\
\hline School Social Capital Structure & & & & \\
Emphasis on academics & 1.285 & .021 & .780 & .269 \\
Minority percent of enrolled & -.001 & .802 & -.008 & .235 \\
Percent in free \& reduced lunch & -.006 & .324 & -.005 & .511 \\
School enrollment & .0002 & .420 & -.0002 & .500 \\
Average student attendance rate & .011 & .709 & .005 & .894 \\
School Social Capital Process & & & & \\
Talks to teacher outside class & -.181 & .000 & -.118 & .071 \\
Teacher is nurturing to student & -.097 & .473 & .009 & .959 \\
No. of school orgs. involved in & -.104 & .001 & -.088 & .036 \\
Amount that parents contact school & -.312 & .122 & -.407 & .122 \\
Parent involved with other school & -.139 & .410 & .108 & 623 \\
$\quad$ organizations & & & & \\
Amt. parent's volunteer for PTO & .120 & .064 & -.002 & .984 \\
Community Social Capital Structure & & & & \\
Residential stability & -.036 & .038 & -.034 & .121 \\
Residential longevity & .127 & .050 & -.081 & .327 \\
Percent commuting: metro core & -.014 & .038 & -.005 & .560 \\
$\quad$ other metro & -.015 & .027 & -.018 & .035 \\
$\quad$ adj. Nonmetro & -.022 & .028 & -.008 & .507 \\
$\quad$ nonadjacent & -.019 & .217 & -.003 & .871 \\
$\quad .002$ & .847 & .029 & .023 \\
Voter participation & & & & \\
Community Social Capital Process & .275 & .094 & .429 & .046 \\
Student belongs to religious grp. & -.066 & .422 & -.185 & .087 \\
Number of nonreligious groups student & & & & \\
involved in & .321 & .142 & .161 & .574 \\
Number of leadership positions & -.024 & .647 & .217 & .002 \\
No. of times changed school & .020 & .683 & -.144 & .021 \\
Parent knows child's friends parents & & & &
\end{tabular}


TABLE 6

Summary Model Statistics for Hierarchical Linear Models of the Effect of Social Capital on $8^{\text {th }}$ Grade Test Scores

\begin{tabular}{|c|c|c|c|c|c|c|c|c|c|}
\hline \multirow[b]{2}{*}{ Math IRT } & \multicolumn{2}{|c|}{ Metro Core } & \multicolumn{2}{|c|}{$\underline{\text { Other Metro }}$} & \multicolumn{2}{|c|}{$\underline{\text { Adjacent Nonmetro }}$} & \multicolumn{2}{|c|}{$\underline{\text { Non-adj. Nonmetro }}$} & \multirow[b]{2}{*}{$\begin{array}{l}-2 \text { log- } \\
\text { likelihood }\end{array}$} \\
\hline & $\begin{array}{c}\text { Student } \\
\text { variance }\end{array}$ & $\begin{array}{c}\text { School \& } \\
\text { community } \\
\text { variance } \\
\end{array}$ & $\begin{array}{c}\text { Student } \\
\text { variance }\end{array}$ & $\begin{array}{c}\text { School \& } \\
\text { community } \\
\text { variance }\end{array}$ & $\begin{array}{c}\text { Student } \\
\text { variance }\end{array}$ & $\begin{array}{c}\text { School \& } \\
\text { community } \\
\text { variance }\end{array}$ & $\begin{array}{c}\text { Student } \\
\text { variance }\end{array}$ & $\begin{array}{c}\text { School \& } \\
\text { community } \\
\text { variance }\end{array}$ & \\
\hline Intercept only & 59.071 & 17.283 & 62.680 & 9.655 & 54.623 & 9.415 & 55.787 & 10.987 & 65,114 \\
\hline Student ability \& background & 36.248 & 6.480 & 37.282 & 6.130 & 36.546 & 7.272 & 37.433 & 7.367 & 60,696 \\
\hline Resources & 36.160 & 3.677 & 36.576 & 4.521 & 36.254 & 5.843 & 36.675 & 7.237 & 60,467 \\
\hline Family social capital & 34.357 & 2.917 & 34.828 & 3.735 & 35.616 & 5.124 & 34.911 & 6.577 & 60,013 \\
\hline School social capital & 33.864 & 1.814 & 34.366 & 3.340 & 35.257 & 4.108 & 34.644 & 4.446 & 59,844 \\
\hline Community social capital & 33.668 & 1.704 & 34.129 & 2.881 & 35.289 & 4.250 & 34.441 & 4.005 & 59,821 \\
\hline $\mathrm{R}^{2}$ & \multicolumn{2}{|c|}{.537} & \multicolumn{2}{|c|}{.488} & \multicolumn{2}{|c|}{.382} & \multicolumn{2}{|c|}{.424} & \\
\hline \multicolumn{10}{|l|}{$\overline{\text { Reading IRT }}$} \\
\hline \multirow{2}{*}{$\begin{array}{l}\text { Intercept only } \\
\text { Student ability \& background }\end{array}$} & 58.422 & 11.453 & 68.549 & 5.513 & 59.926 & 7.018 & 66.075 & 6.315 & 65,519 \\
\hline & 44.016 & 3.549 & 48.139 & 3.227 & 44.573 & 4.991 & 46.380 & 5.455 & 62,441 \\
\hline Resources & 43.652 & 2.479 & 47.469 & 2.298 & 44.055 & 4.005 & 45.294 & 5.027 & 62,260 \\
\hline Family social capital & 41.473 & 1.931 & 45.265 & 1.800 & 42.828 & 3.399 & 43.030 & 4.473 & 61,799 \\
\hline School social capital & 40.711 & 1.327 & 45.144 & 1.609 & 42.964 & 2.897 & 42.344 & 3.392 & 61,703 \\
\hline Community social capital & 40.530 & 1.220 & 44.574 & 1.459 & 42.325 & 3.117 & 41.878 & 2.822 & 61,701 \\
\hline $\mathrm{R}^{2}$ & \multicolumn{2}{|r|}{.403} & \multicolumn{2}{|r|}{.378} & \multicolumn{2}{|c|}{.321} & \multicolumn{2}{|c|}{.383} & \\
\hline
\end{tabular}


TABLE 7

Summary Model Statistics for Hierarchical Linear Models of the Effect of Social Capital for Gains on Test Scores

\begin{tabular}{|c|c|c|c|c|c|c|c|c|c|}
\hline Math Gain & $\begin{array}{c}\text { Student } \\
\text { variance }\end{array}$ & $\begin{array}{l}\text { ro Core } \\
\text { School \& } \\
\text { community } \\
\text { variance }\end{array}$ & $\begin{array}{c}\text { Student } \\
\text { variance }\end{array}$ & $\begin{array}{l}\text { r Metro } \\
\text { School \& } \\
\text { community } \\
\text { variance }\end{array}$ & $\begin{array}{l}\text { Adjacen } \\
\text { Student } \\
\text { variance }\end{array}$ & $\begin{array}{l}\text { Nonmetro } \\
\text { School \& } \\
\text { community } \\
\text { variance }\end{array}$ & $\begin{array}{c}\text { Student } \\
\text { variance }\end{array}$ & $\begin{array}{c}\text { Nonmetro } \\
\text { School \& } \\
\text { community } \\
\text { variance }\end{array}$ & $\begin{array}{c}-2 \text { log- } \\
\text { likelihood }\end{array}$ \\
\hline Intercept only & 26.544 & 1.300 & 29.136 & 1.993 & 30.876 & 5.084 & 31.336 & 2.338 & 35,467 \\
\hline $8^{\text {th }}$ grade test score & 26.427 & 1.411 & 29.089 & 2.029 & 30.777 & 5.098 & 31.485 & 2.251 & 35,469 \\
\hline Student ability \& background & 24.795 & 1.446 & 26.679 & 2.055 & 28.036 & 4.914 & 29.342 & 1.995 & 35,061 \\
\hline Resources & 24.573 & 1.070 & 26.423 & 1.546 & 27.600 & 3.839 & 29.659 & 1.564 & 34,987 \\
\hline Family social capital & 24.320 & 1.077 & 26.144 & 1.461 & 26.942 & 3.531 & 28.708 & 1.589 & 34,905 \\
\hline School social capital & 24.181 & 0.892 & 26.104 & 1.362 & 26.666 & 3.423 & 28.735 & 1.901 & 34,917 \\
\hline Community social capital & 24.171 & 0.962 & 26.072 & 1.406 & 26.581 & 3.250 & 28.666 & 1.853 & 34,964 \\
\hline $\mathrm{R}^{2}$ & \multicolumn{2}{|c|}{.097} & \multicolumn{2}{|c|}{.117} & \multicolumn{2}{|c|}{.170} & \multicolumn{2}{|c|}{.094} & \\
\hline \multicolumn{10}{|l|}{ Reading Gain } \\
\hline Intercept only & 45.888 & 2.459 & 52.546 & 2.581 & 48.190 & 4.550 & 43.897 & 3.536 & 38,295 \\
\hline $8^{\text {th }}$ grade test score & 45.125 & 2.692 & 51.331 & 2.840 & 47.460 & 4.696 & 43.267 & 3.419 & 38,213 \\
\hline Student ability \& background & 43.044 & 1.955 & 48.382 & 2.974 & 45.721 & 4.502 & 42.837 & 3.116 & 37,963 \\
\hline Resources & 42.854 & 1.647 & 48.319 & 2.601 & 45.851 & 3.792 & 43.092 & 2.746 & 37,955 \\
\hline Family social capital & 42.406 & 1.799 & 47.636 & 2.208 & 44.839 & 3.534 & 42.358 & 2.825 & 37,874 \\
\hline School social capital & 42.374 & 1.828 & 47.349 & 2.344 & 44.968 & 3.261 & 42.194 & 3.022 & 37,955 \\
\hline Community social capital & 41.935 & 1.688 & 47.476 & 2.167 & 44.853 & 2.730 & 41.954 & 2.744 & 37,912 \\
\hline $\mathrm{R}^{2}$ & \multicolumn{2}{|c|}{.098} & \multicolumn{2}{|c|}{.099} & \multicolumn{2}{|c|}{.098} & \multicolumn{2}{|r|}{.058} & \\
\hline
\end{tabular}




\section{CONCLUSIONS AND DISCUSSION}

In this study, we examined a comprehensive set of factors that might be incorporated into community efforts aimed at creating a pool of high-quality workers. We did so by articulating how the strength of social capital present in the family and school, and in the community in which these institutions are embedded, might lead to improvements in student achievement. We argued that achievement on standardized tests is an early marker of the future human capital resources available to support local economic growth.

We explored the influence of social capital on $8^{\text {th }}$ grade test scores and gains from the $8^{\text {th }}$ to $12^{\text {th }}$ grades for math and reading. Examining educational outcomes in terms of students' activities, participation and behavior, course selection, and ability proved fruitful. Most of these variables helped to explain the variance in test scores and gains. In the end, our findings reaffirmed the significant role of parents in giving shape to the educational progress of their children. Family resources also played an important role in promoting academic success. In addition, a number of measures of social capital in the school and community had a significant effect on test scores and gains. Finally, the contextual aspects of school and community structure mediated the influence of family social capital, student ability, and background on student achievement.

The results support the view that youths' academic success stands on a three-legged stool - families, schools, and communities. Because efforts to raise student achievement focus almost exclusively on the school, new approaches for improving student performance remain school-centered in their orientations. Our results show that enhancing family capacity should be viewed as a critical ingredient in promoting the educational achievement of students. As such, a conscientious effort must be made to design and deliver an array of programs that could help build parent competencies and facilitate the creation of social capital in the home. Included could be tools to promote high-quality parent-child interactions, building children's self-confidence, and raising their educational aspirations. Also included in the toolkit for parents could be activities that can help curb behaviors by their children that might inhibit their academic progress. When taken together, these types of strategies help establish a home environment where parent-child relationships are strong, and where parents express a high regard for education.

Although community social capital may be less significant in influencing a student's academic achievement, one should not disregard community social capital as a potential resource. Community social capital likely influences high school students' educational performance through the variety of programs, organizations, and activities available in a locality. Community leaders might work with teachers to develop service-learning projects of interest to parents, students, and teachers that foster relationships outside of the classroom. Community service learning projects, such as community visioning or asset mapping, youth entrepreneurship, and delivery of services to elders or peers, can teach youth how to engage in civic affairs, enhance integration of new students, and help address local needs. Through their participation, citizens convey the importance of high 
educational performance to children and help students to develop the skills necessary to succeed.

Localities differ in their ability to enhance community social capital. Inequality, isolation, dependency, and gaps in the organizational and institutional structure can inhibit action on the part of communities and schools. We found that students attending schools in rural (nonadjacent nonmetropolitan) areas face a set of structural conditions that work against academic success. Until these structural deficiencies are confronted, many communities will be unable to muster the social capital needed to make a real difference in the life chances of local youth.

\section{REFERENCES}

Aldrich, L. and L. Kusmin, 1997. Rural Economic Development: What Makes Rural Communities Grow? Economic Research Service Agriculture Information Bulletin No. 737 (September).

Alexander, K. and B. Eckland, 1975. "Contextual Effects in the High School Attainment Process,” American Sociological Review 40(3), 402-416.

Amrein, A. and D. Berliner, 2002. The Impact of High Stakes Tests on Student Academic Performance. Education Policy Studies Laboratory Report, University of Arizona. EPSL-0211-126-EPRU (December).

Arum, R., 1998. "Invested Dollars or Diverted Dreams: The Effect of Resources on Vocational Students' Educational Outcomes,” Sociology of Education 71( 2), 130-151.

Ballou, D. and M. Podgursky, 1998. "Rural Teachers and Schools," in R.M. Gibbs, P.L. Swaim, and R. Teixeira (eds.), Rural Education and Training in the New Economy: The Myth of the Rural Skills Gap. Ames: Iowa State Press, 3-21.

Barkley, D.L., M.S. Henry, and B. Shuming, 1998. "The Role of Local School Quality in Rural Employment and Population Growth,” Review of Regional Studies 28(1), 81-102.

Beaulieu, L.J. and G.D. Israel, 1997. "Strengthening Social Capital: The Challenge for Rural Community Sustainability,” in I. Audirac (ed.), Rural Sustainable Development in America. New York: Wiley, 191-223.

Beaulieu, L.J., G.D. Israel, G. Hartless, and P. Dyk, 2001. "For Whom Does the School Bell Toll? Multi-Contextual Presence of Social Capital and Student Educational Achievement," The Journal of Socio-Economics 30, 121-127.

Blake, J., 1981. "Family Size and the Quality of Children," Demography 18, 421-42.

Blau, P.M., 1960. "Structural Effects,” American Sociological Review 25(2), 178-93. 1994. Structural Contexts of Opportunities. Chicago: University of Chicago Press.

Bogenschneider, K., 1997. "An Ecological Risk/Protective Theory for Building Prevention Programs, Policies, and Community Capacity to Support Youth,” Family Relations 45, 127-38.

Butler, M.A. and C.L. Beale, 1994. Rural-Urban Continuum Codes of Metro and Nonmetro Counties 1993. Washington, D.C.: U.S. Dept. of Agriculture, Economic Research Service.

Carbonaro, W.J., 1999. "Opening the Debate on Closure and Schooling Outcomes," American Sociological Review 64, 682-686. 
Cobb, R.A., W.G. McIntyre, and P.A. Pratt, 1989. 'Vocational and Educational Aspirations of High School Students: A Problem for Rural America,” Research in Rural Education 6(2), 11-15.

Coleman, J.S., 1988. "Social Capital in the Creation of Human Capital," American Journal of Sociology 94 (Suppl.), 95-120. 1990. Equality and Achievement in Education. Boulder: Westview Press.

Coleman, J.S. and T. Hoffer, 1987. Public and Private High Schools: The Impact of Communities. New York: Basic Books.

Coleman, J.S., E. Campbell, C. Hobson, J. McPartland, A. Mood, F. Weinfeld, and R. York, 1966. Equality of Educational Opportunity. Washington, D.C.: U.S. Government Printing Office.

Downey, D.B. 1995. "When Bigger Is Not Better: Family Size, Parental Resources, and Children’s Educational Performance," American Sociological Review 60, 746-761.

Duncan, O.D., D.L Featherman, and B. Duncan, 1972. Socioeconomic Background and Achievement. New York: Seminar Press.

Eccles, J.S. and R.D. Harold, 1993. "Parent Involvement During the Early Adolescent Years," Teachers College Record 94(3), 568-87.

Ekstrom, R.B., M.E. Goertz, J.M. Pollack, and D.A. Rock, 1986. "Who Drops out of High School and Why? Findings From a National Study," Teacher College Record 3, 35673.

Flinn, J.D. and D.A. Rock, 1997. "Academic Success Among Students at Risk for School Failure,” Journal of Applied Psychology 82(2), 221-234.

Flora, J.L., 1998. "Social Capital and Communities of Place,” Rural Sociology 63, 481-506.

Flora, C.B., J.L. Flora, and S. Fey, 2004. Rural Communities: Legacy and Change. Boulder, CO: Westview Press.

Friedkin, N. and J. Necochea, 1988. "School System Size and Performance: A Contingency Perspective," Educational Evaluation and Policy Analysis 10(3), 237-249.

Gale Jr., H.F., T.R. Wojan, and J.C. Olmsted, 2002. "Skills, Flexible Manufacturing Technology, and Work Organization,” Industrial Relations 41(1), 48-79.

Gibbs, R.M., P.L. Swaim, and R. Teixeira (eds.), 1998. Rural Education and Training in the New Economy: The Myth of the Rural Skills Gap. Ames, IA: Iowa State Press.

Granovetter, M., 1973. "The Strength of Weak Ties," American Journal of Sociology 78, 1360-80.

Greenberg, E.J. and R. Teixeira, 1998. "Educational Achievement in Rural Schools,” in R.M. Gibbs, P.L. Swaim, and R. Teixeira (eds.), Rural Education and Training in the New Economy: The Myth of the Rural Skills Gap. Ames, IA: Iowa State University Press, 23-39.

Greenwald, R., L.V. Hedges, and R.D. Laine, 1996. "The Effect of School Resources on Student Achievement," Review of Educational Research 66(3), 361-396.

Gregory, T.B. and G.R. Smith, 1987. High Schools As Communities: The Small School Reconsidered. Bloomington, IN: Phi Delta Kappa Educational Foundation.

Hobbs, D., 1995. "Capacity-Building: Reexamining the Role of the Rural School,” in L.J. Beaulieu and D. Mulkey (eds.), Investing in People: The Human Capital Needs of Rural America. Boulder: Westview Press, 259-84.

Hoffer, T., A. Greeley, and J. Coleman, 1987. "Catholic High School Effects on Achievement Growth,” in E. Haertel, T. James, and H. Levin (eds.), Comparing Public and Private Schools, Vol. 2, School Achievement. New York: Falmer. 
Ingels, S.J., L.A. Scott, J.R. Taylor, J. Owings, and P. Quinn, 1998. National Education Longitudinal Study of 1988 (NELS:88) Base Year Through Second Follow-Up: Final Methodology Report. U.S. Department of Education, National Center for Education Statistics. Working Paper No. 98-06.

Israel, G.D., L.J. Beaulieu, and G. Hartless, 2001. "The Influence of Family and Community Social Capital on Educational Achievement," Rural Sociology 66(1), 43-68.

Jensen, L. and D.K. McLaughlin, 1995. "Human Capital and Nonmetropolitan Poverty." in L.J. Beaulieu and D. Mulkey (eds.), Investing in People: The Human Capital Needs of Rural America. Boulder: Westview Press, 111-38.

Kohn, A., 2000. The Case Against Standardized Testing: Raising the Scores, Ruining the Schools. Portsmouth, NH: Heinemann.

Lee, V.F. and J.B. Smith, 1996. "Collective Responsibility for Learning and Its Effect on Gains in Achievement for Early Secondary Students," American Journal of Education 104, 103-147.

Lerner, R.M., 1995. America's Youth in Crisis: Challenges and Options for Programs and Policies. Thousand Oaks, CA: Sage.

Lichter, D.T., L.J. Beaulieu, J.L. Findeis, and R.A. Teixeira, 1993. "Human Capital, Labor Supply, and Poverty in Rural America," in Rural Sociological Society Task Force on Persistent Rural Poverty (ed.), Persistent Poverty in Rural America. Boulder, CO: Westview Press, 39-67.

Luloff, A.E. and K. Wilkinson, 1979. "Participation in the National Flood Insurance Program: A Study of Community Activeness,” Rural Sociology 44, 137-52.

McCall, J., 1997. "Education and Economic Development," Planning Commissioners Journal (Summer), 4.

McGranahan, D.A., 2002. "Local Context and Advanced Technology Use by Small, Independent Manufacturers in Rural Areas," American Journal of Agricultural Economics 84(5), 1237-1245.

McNeal, R.B., Jr., 1999. "Parental Involvement as Social Capital: Differential Effectiveness on Science Achievement, Truancy, and Dropping Out,” Social Forces 78(1), 117-144. , 2001. "Differential Effects of Parental Involvement on Cognitive and Behavioral Outcomes by Socioeconomic Status," The Journal of Socio-Economics 30(2), 171.

Morgan, S.L. and A.B. Sørensen, 1999. "Parental Networks, Social Closure, and Mathematics Learning: A Test of Coleman's Social Capital Explanation of School Effects," American Sociological Review 64, 661-81.

Mortimore, P., P. Sammons, L. Stoll, D. Lewis, and R. Ecob, 1988. School Matters. Berkeley: University of California Press.

Noddings, N., 1988. “Schools Face Crisis in Caring,” Education Week 8, 32.

Parcel, T.L. and M.J. Dufur, 2001. "Capital at Home and at School: Effects on Student Achievement,” Social Forces 79(3), 881-911.

Putnam, R.D., 2000. Bowling Alone: The Collapse and Revival of American Community. New York: Simon and Schuster.

Rossi, R. and S. Daugherty, 1996. How Safe Are the Public Schools: What do Teachers Say? National Center for Education Statistics Issue Brief (NCES-96-842). Washington, D.C.: National Center for Education Statistics.

Rutter, M., B. Maughan, P. Mortimore, and J. Ouston, 1979. Fifteen Thousand Hours: Secondary Schools and Their Effects on Children. Cambridge, MA: Harvard University Press. 
Scales, P.C. and E.C. Roehlkepartain, 2003. "Boosting Student Achievement: New Research on the Power of Developmental Assets," Search Institute Insights and Evidence 1(1), 1-10.

Schneider, B., 1993. "Parents, Their Children, and Schools: An Introduction," in B. Schneider and J.S. Coleman (eds.), Parents, Their Children, and Schools. Boulder, CO: Westview Press, 1-12.

Sher, J.P., 1988. Class Dismissed: Examining Nebraska's Rural Education Debate. Hildreth, NE: Nebraska Rural Community Schools Association.

Smith, M.H., L.J. Beaulieu, and G.D. Israel, 1992. "Effects of Human Capital and Social Capital on Dropping out of High School in the South," Journal of Research in Rural Education 8(1), 75-88.

Smith, M.H., L.J. Beaulieu, and A. Seraphine. 1995. "Social Capital, Place of Residence, and College Attendance,” Rural Sociology 60, 363-80.

Stevenson, D.L. and D.P. Baker, 1987. "The Family-School Relations and the Child's School Performance," Child Development 58, 1348-57.

Stockard, J. and M. Mayberry, 1992. Effective Educational Environments. Newbury Park, CA: Corwin.

Teachman, J.D., K. Paasch, and K. Carver, 1997. "Social Capital and the Generation of Human Capital,” Social Forces 75(4), 1343-1359.

Turner, R., G. Camilli, R. Kroc, and J. Hoover, 1986. "Policy Strategies, Teacher Salary Incentive and Student Achievement: An Exploratory Model," Educational Researcher 15(3), 5-11.

U.S. Department of Education, 2002. No Child Left Behind: A Desktop Reference. Washington, DC: Office of Elementary and Secondary Education. , 2003. The Condition of Education 2003. National Center for Education Statistics. NCES 2003-067. Washington, DC.

Walberg, H.J., 1984. "Improving the Productivity of America's Schools," Educational Leadership 41, 19-47.

Walberg, H.J and W. Fowler, 1987. "Expenditure and Size Efficiencies of Public School Districts,” Educational Researcher 16(7), 5-13.

Wall, E., G. Ferrazzi, and F. Schryer, 1998. "Getting the Goods on Social Capital,” Rural Sociology 63, 300-22.

Wenglinsky, H., 1997. "How Money Matters: The Effect of School District Spending on Academic Achievement," Sociology of Education 70(3), 221-237.

Werner, E. and R. Smith, 1989. Vulnerable but Invincible: A Longitudinal Study of Resilient Children and Youth. New York: Adams, Bannister, and Cox.

Wilkinson, K.P., 1991. The Community in Rural America. Westport, CT: Greenwood.

Zekeri, A.A., K.P. Wilkinson, and C.R. Humphrey, 1994. "Past Activeness, Solidarity, and Local Development Efforts,” Rural Sociology 59, 216-35. 